Plant Tissue Cult. \& Biotech. 29(2): 195-205, 2019 (December)

CBangladesh Assoc. for Plant Tissue Culture \& Biotechnology

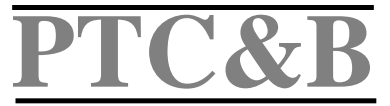

\title{
Efficient Shoot Regeneration via Indirect Organaogenesis of A Highly Recalcitrant Species of Cissampelos pareira $\mathrm{L}$.
}

\author{
C. M. Narendra Reddy, P. V. Chaithanya Lakshmi, V. N. Swetha \\ Prasuna, M. Raja Gopal and B. Srinivas* \\ Department of Biotechnology, School of Herbal Studies and Natural Sciences, Dravidian \\ University, Kuppam-517426, Andhra Pradesh, India
}

Key words: Organogenesis, Regeneration, Nodal explants, Cissampelos pareira

\begin{abstract}
An efficient protocol was standardized for successful regeneration of Cissampelos pareira (L.) through indirect organogenesis. Nodal explants were cultured on MS fortified with $0.5 \pm 1.0 \mathrm{mg} / \mathrm{BAP}, \mathrm{Kn}$ either single or in combination with NAA $0.5 \mathrm{mg}$. The combinations induced profuse, compact, light green to greenish coloured calli. Some differences in the morphology of callus such as change in the colour and texture was also observed with increasing the concentration of BAP $0.5 \pm 2.0 \mathrm{mg} \Lambda+\mathrm{NAA} 0.5 \mathrm{mg} \Lambda$. Maximum callus induction was observed on $1.0 \mathrm{mg} / \mathrm{BAP}$ and $0.5 \mathrm{mg} / \mathrm{NAA}$ showed greenish, friable and granular lush colour. The calli were subcultured on fresh MS that contained BAP and $\mathrm{Kn}$ single or in combination with NAA (BAP $0.5 \pm 2.0 \mathrm{mg} / \mathrm{Kn} 0.5 \pm$ $2.0 \mathrm{mg} \Lambda$, NAA $0.5 \mathrm{mg} /$ ). The maximum regeneration frequency of shoot organogenesis was recorded on BAP $(2.0 \mathrm{mg} \Lambda)+\mathrm{NAA}(0.5 \mathrm{mg} \Lambda)$. Healthy microshoots were separated and transferred to the rooting medium. Here, MS augmented with IBA $1.0 \mathrm{mg} /$ showed maximum rooting. Well rooted plantlets were transferred to the field and maximum survival frequency was recorded when BAP $(1.0 \mathrm{mg} \Lambda)+\mathrm{NAA}(0.5 \mathrm{mg} \Lambda)$ for callus induction, for shooting BAP $(2.0 \mathrm{mg} \Lambda)+\mathrm{NAA}(0.5 \mathrm{mg} \Lambda)$ and for rooting IBA $(1.0 \mathrm{mg} \Lambda)$ was used. The regenerated whole plants were subjected for hardening where the maximum survival frequency was found to be $80 \%$. This reproducible protocol can be used for regeneration and genetic transformation studies.
\end{abstract}

\section{Introduction}

Menispermaceae is one of the most important families contains more than 70 genera and 500 species with medicinal values. It is also called as moon seed family (Ortiz et al. 2007). Cissampelos pareira $\mathrm{L}$. is one of the important medicinal plants for industrial and other

*Author for correspondence: \bathulasrinivas71@gmail.com>

DOI: https://doi.org/10.3329/ptcb.v29i2.44508 
economic values (Mridula et al. 2017). In Ayurveda and Siddha medicines, C. pareira is called as "Lagu patta" and "Malaith thaangki". It is commonly known as Patha, velvet leaf, ice vine, patindu and abuta (Vaidya 1988).

In telugu it is known as "Adavi banka theega". It has been distributed throughout the tropical, sub-tropical and hilly regions of India such as Andhra Pradesh, Himachal Pradesh, Karnataka, Tamilnadu, Kerala etc. up to $1500 \mathrm{~m}$ elevation (Shad and Deepa 2015). Various reports on its multiple medicinal use attracted attention for commercial exploitation of the plant to meet the requirements of the growing pharmaceutical industry. Cissampelos pareira natural stands are now fast disappearing and are threatened due to indiscriminate collection and over-exploitation. Conventional vegetative propagation of this plant has limited potential for large scale cultivation. In vitro micropropagation technique can be most useful for its mass propagation as well as for its conservation.

In in vitro conditions, plant regeneration occurs through direct and indirect organogenesis. Previously, direct organogenesis was reported in one of the Menispermaceae member, Tinospora cardifolia through nodal explants (Kumar et al. 2003, Raghu et al. 2006, Gururaj et al. 2007, Sharma and Vashistha 2014). Some of the in vitro studies were made on Agrobacterium rhizogenes-mediated transformation of C. pareira (Shad and Deepa 2015). Due to poor seed viability, in naturally grown plants, low germination and high susceptibility of infections the plant growth is hampered. In short span of time large number of healthy plantlets can be produced through direct and callus mediated shoot induction method. Moreover, the standardization of callus production and cell culture protocols could be an effective alternative for the bioactive compound production and minimize the pressure on the wild population. The present study was aimed at developing efficient mass multiplication of $C$. pareira via indirect organogenesis.

\section{Materials and Methods}

The axillary buds of Cissampelos pareira (L.) was collected from the Herbal garden, Department of Biotechnology, Dravidian University, Kuppam, Andhra Pradesh, India. As explants nodes were collected from field grown disease free healthy plants.

The explants were washed in running tap water for $10 \mathrm{~min}$ and then washed with liquid detergent solution $5 \%(\mathrm{v} / \mathrm{N})$ Tween-20 or Teepol for $20 \mathrm{~min}$ followed by continuous washing with distilled water until all the traces of detergent was removed. Then the explants were surface sterilized with $0.4 \%(\mathrm{w} / \mathrm{N})$ bavistin a systematic fungicide (BASF India Ltd.) for about 15 to $20 \mathrm{~min}$. After fungicide sterilizing, the explants were surface sterilized with $70 \%$ ethanol for $90 \mathrm{sec}$. Then the explants were surface sterilized with $0.1 \%$ mercuric chloride (Merck, India) for $1-3$ min under laminar air flow cabinet and thoroughly washed with double distilled water for $5-6$ times. Finally the sterilized explants were slightly trimmed by cutting into small pieces of size $1.0-1.5 \mathrm{~cm}$ and 
wounded slightly. All explants were placed and cultured horizontally by placing the wounds in contact with the medium.

MS supplemented with auxins and cytokinins at different concentrations either single or in combination for callus and shoot proliferation. Nodal explants were cultured on MS supplemented with different concentrations and combinations of BAP, Kn $0.5 \pm$ $2.0 \mathrm{mg} /$ and NAA at $0.5 \mathrm{mg} /$ for callus initiation and proliferation. The medium without plant growth regulators served as control and $100 \mathrm{mg} /$ of ascorbic acid added to the medium to reduce tissue browning. In vitro calli were sub-cultured repeatedly for every 20 days for respective medium. In vitro induced callus on the cultures have been transferred in to the shoot induction medium containing BAP $0.5 \pm 2.0 \mathrm{mg} /$ and NAA 0.5 $\mathrm{mg}$ A. Nodal explants were simultaneously cultured on the same medium for shoot bud induction and multiplication.

The shoot bud callus was transferred in to the shoot elongation MS supplemented with BAP at $0.5-2.0 \mathrm{mg} \Lambda$ and NAA $0.5 \mathrm{mg}$. The elongated shoots were then transferred to the root induced half strength MS fortified with $0.2-1.0 \mathrm{mg} /$ NAA and IBA. Well developed rooted plantlets were separated from the culture tubes, thoroughly washed and transferred in to the polybags containing sterile red soil and vermiculite at $1: 1$ $(\mathrm{w} / \mathrm{w})$ for hardening. The potted plantlets were maintained under in vitro condition for six weeks and then finally transferred to the field condition.

All the experiments were conducted in randomly designed and each contains 10 explants per treatment and the experiment was repeated at least three times. The data on callus induction, shoot bud differentiation, root initiation and number of shoot and root were recorded at regular intervals. All the data were analyzed by ANOVA using SPSS software version 16.0 (IBM SPSS, IL). Mean was compared using DMRT at 5\% significance.

\section{Results and Discussion}

The data revealed that different auxins and cytokinins at various concentrations showed potential effect on callus induction. Then the medium boosted with BAP $(0.5-2.0 \mathrm{mg} /)$, NAA $(0.5 \mathrm{mg} /)$ and $\mathrm{Kn}(0.5-2.0 \mathrm{mg} /)$. Induction of callus was observed after 3 weeks of inoculation. The addition of either BAP $(1.0 \mathrm{mg} \Lambda)$ or $\mathrm{Kn}(1.0 \mathrm{mg} \Lambda)$ had less effect in promoting callus formation when compared with combination of BAP + NAA $(1.0 \mathrm{mg} A+$ $0.5 \mathrm{mg}$ ) (Fig. 1a, b). The callus formation was initiated differently from the centre portion of the explants and cut end of nodule buds. The frequency of callus induction $(80 \%)$ was observed in $1.0 \mathrm{mg} \Lambda \mathrm{BAP}$ and it was reduced from 1.5 to $2.0 \mathrm{mg} \Lambda$ of BAP (Fig. 1b). Further, by the increase of BAP concentration the callus induction frequency decreased. Surprisingly when the explants were cultured on MS containing both BAP (1.0 mg $/$ ) and NAA (0.5 mg $/$ ) induced maximum callus induction frequency (95\%) compared to BAP and Kn single usages (Fig. 1c). The callus induction frequency $(90 \%)$ was highly effective with the combination of $\mathrm{Kn}+\mathrm{NAA}(1.0 \mathrm{mg} \Lambda+0.5 \mathrm{mg} \Lambda)$ and single 
usages of $\mathrm{Kn}(1.0 \mathrm{mg} \Lambda)$ is found to be less effective in callus induced frequency $(80 \%)$. The color and texture of the callus differed depending upon the type of auxin used. The morphology of regenerated callus in terms of colour and texture was light green to creamish colour. The combination of BAP and NAA exhibited high quality colour and profuse organic in texture (Fig. 1c).
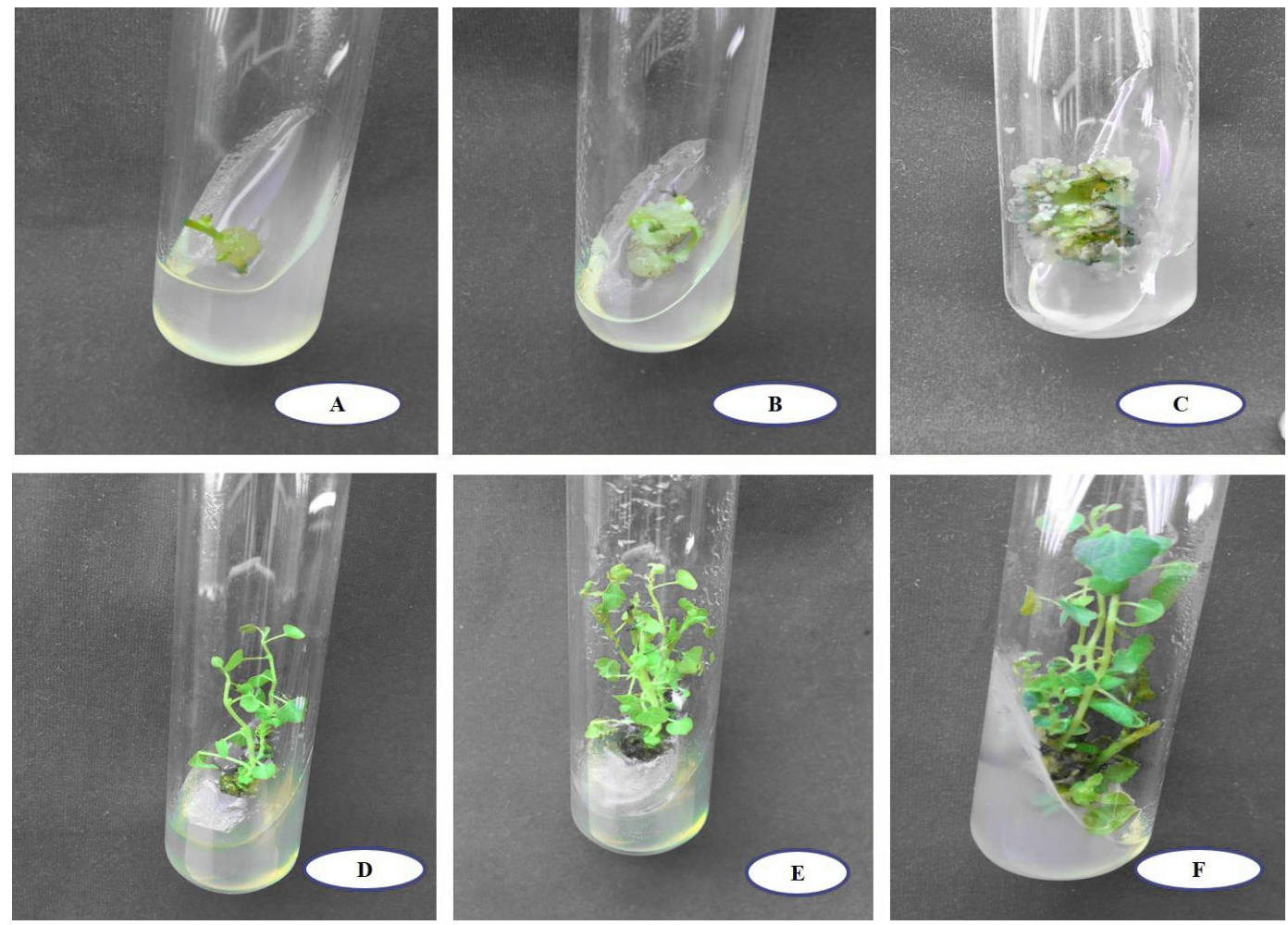

Fig. 1(a-f): Callus induction from nodal explants and regeneration from the calli. (a) Nodal explants cultured on $1.0 \mathrm{mg} /$ BAP medium. (b) Callus induction after 3 weeks old culture. (c) Induction of greenish colour, high quality texture and profuse callus of 6 weeks old culture. (d) Indirect shoot regeneration from BAP (2.0 $\mathrm{mg} /)$. (e) Indirect shoot proliferation. (f) BAP $(2.0 \mathrm{mg} /)$ and NAA $(0.5 \mathrm{mg} \Lambda)$ resulted maximum frequency of adventitious shoot regeneration after 8 weeks of sub-culturing.

There are several reports on 2,4-D which has positive effective on callus induction (Chandra et al. 2014 and Das et al. 2017 ) but in the present study, it was found that 2,4-D had least effect on callus induction in C. pareira. It was tested on 5 weeks old culture on MS containing 2,4-D (2.0 mg $\Lambda)$ along with BAP $(0.5 \mathrm{mg} \Lambda)$ and found to have less effective for callus induction. Similarly MS containing IAA along with BAP was also found to be less effective on callus induction of C. pareira. (Data not shown). 
Table 1. Effect of different concentrations of auxins and cytokinins on callus induction from nodal explants.

\begin{tabular}{|c|c|c|c|c|c|}
\hline \multicolumn{3}{|c|}{$\begin{array}{l}\text { Plant growth regulators } \\
\qquad(\mathrm{mg} \Lambda)\end{array}$} & \multirow{2}{*}{$\begin{array}{l}\text { Callus } \\
\text { proliferation } \\
\text { rate }\end{array}$} & \multirow{2}{*}{$\begin{array}{l}\text { Frequency of } \\
\text { callus induction } \\
(\%)\end{array}$} & \multirow{2}{*}{$\begin{array}{l}\text { Callus characteristics on the } \\
\text { basis of colour and texture }\end{array}$} \\
\hline BAP & NAA & Kn & & & \\
\hline 0.5 & - & - & $\mathrm{C}^{+}$ & 60 & Yellowish green \\
\hline 1.0 & - & - & $\mathrm{C}^{+++}$ & 80 & Greenish white fragile \\
\hline 1.5 & - & - & $\mathrm{C}^{+}$ & 70 & Brown compact \\
\hline 2.0 & - & - & $\mathrm{C}^{++}$ & 70 & Brown compact, fragile \\
\hline 0.5 & 0.5 & - & $\mathrm{C}^{+}$ & 75 & Brown, fragile \\
\hline 1.0 & 0.5 & - & $\mathrm{C}^{+++}$ & 95 & Greenish, fragile, granular lush \\
\hline 1.5 & 0.5 & - & $\mathrm{C}^{++}$ & 85 & Yellow greenish, fragile \\
\hline 2.0 & 0.5 & - & $\mathrm{C}^{++}$ & 90 & Greenish, fragile, granular \\
\hline- & 0.5 & 0.5 & $\mathrm{C}^{+}$ & 60 & Yellows green, fragile \\
\hline- & 0.5 & 1.0 & $\mathrm{C}^{+++}$ & 90 & Greenish white, fragile \\
\hline- & 0.5 & 1.5 & $\mathrm{C}^{+++}$ & 85 & Greenish fragile \\
\hline- & 0.5 & 2.0 & $\mathrm{C}^{+++}$ & 87 & Light brown, fragile \\
\hline- & - & 0.5 & $\mathrm{C}^{+}$ & 55 & Green, fragile \\
\hline- & - & 1.0 & $\mathrm{C}^{+++}$ & 80 & Light brown, fragile \\
\hline- & - & 1.5 & $\mathrm{C}^{+}$ & 70 & Light green \\
\hline - & - & 2.0 & $\mathrm{C}^{+}$ & 60 & Dark green, compact \\
\hline
\end{tabular}

Sd values are mean \pm of 20 independent determinations, $\mathrm{C}^{+}=$Poor callus $(60 \%)$; $\mathrm{C}^{++}=$Moderate callus $(70 \%) ; C^{++}=$High callus $(80 \%)$ and $C^{+++}=$Very high callus $(95 \%)$. Each and every experiment was conducted with minimum of 10 explants and experiments were repeated Three times.

The callus induction frequency was calculated by using the following formula:

Callus induction frequency $(\%)=\frac{\text { No. of nodal explants produced calli }}{\text { No. of nodal explants cultured }} \times 100$

Well-developed calli were separated and transferred to test tubes and sub-cultured on fresh MS for indirect shoot induction and proliferation. Calli were cultured on BAP (0.5 - $2.0 \mathrm{mg} \Lambda)$, NAA $(0.5 \mathrm{mg} \Lambda)$ and $\mathrm{Kn}(0.5-2.0 \mathrm{mg} /)$. The callus which was produced in maximum in presence of BAP $(1.0 \mathrm{mg} \Lambda)$ and NAA $(0.5 \mathrm{mg} \Lambda)$ was sub-cultured to fresh medium fortified with different concentrations of BAP $(2.0 \mathrm{mg} \Lambda)$ and NAA $(0.5 \mathrm{mg} /)$ for shoot induction changed from light green to dark green colour within 25-30 days of incubation. Shoot induction followed gradual elongation observed after 3 weeks old culture. 
Callus cultured on BAP $(2.0 \mathrm{mg} /)$ alone showed maximum shoot regeneration $(80 \%)$, number of shoots $(4.4 \pm 0.05)$ and length of shoots $(3.8 \pm 0.05 \mathrm{~cm})$ (Fig. 1d). Kn $1.5 \mathrm{mg} /$ produced least regeneration $(55 \%)$ and decreased number of shoots $(3.5 \pm 0.05)$ and length $(2.8 \pm 0.05 \mathrm{~cm})$ (Table 2). Data collection was performed after 4 weeks of inoculation. In all the combinations maximum shoot regeneration was found $(95 \%)$ in BAP $(2.0 \mathrm{mg} \Lambda)$ along with NAA $(0.5 \mathrm{mg} \Lambda)$ produced mean shoot number $(9.8 \pm 0.11)$ and shoot length $(8.3 \pm 0.11 \mathrm{~cm})$ (Fig. 1e,f, Table 2). It was observed that use of BAP singly was not sufficient to produce maximum shoot regeneration.

Table 2. Effect of different concentrations of cytokinins and auxins on indirect shoot organogenesis of in vitro derived callus of $C$. pareira.

\begin{tabular}{|c|c|c|c|c|c|}
\hline \multicolumn{3}{|c|}{$\begin{array}{l}\text { Plant growth regulators } \\
\qquad(\mathrm{mg} \Lambda)\end{array}$} & \multirow{2}{*}{$\begin{array}{l}\text { Shooting frequency } \\
\text { from the callus (\%) }\end{array}$} & \multirow{2}{*}{$\begin{array}{l}\text { Mean values on } \\
\text { shoots/callus }\end{array}$} & \multirow{2}{*}{$\begin{array}{l}\text { Mean values on } \\
\text { shoot length }(\mathrm{cm})\end{array}$} \\
\hline BAP & $\mathrm{Kn}$ & NAA & & & \\
\hline 0.5 & - & - & 59 & $2.3 \pm 0.05^{\mathrm{a}}$ & $1.6 \pm 0.15^{\mathrm{ab}}$ \\
\hline 1.0 & - & - & 65 & $3.2 \pm 0.11^{b}$ & $2.7 \pm 0.11^{\mathrm{d}}$ \\
\hline 1.5 & - & - & 74 & $3.8 \pm 0.05^{c}$ & $3.4 \pm 0.05^{f}$ \\
\hline 2.0 & - & - & 80 & $4.4 \pm 0.05^{\mathrm{d}}$ & $3.8 \pm 0.05^{g}$ \\
\hline- & 0.5 & - & 70 & $2.2 \pm 0.05^{\mathrm{a}}$ & $1.5 \pm 0.05^{\mathrm{a}}$ \\
\hline- & 1.0 & - & 70 & $3.1 \pm 0.05^{b}$ & $2.4 \pm 0.05^{c}$ \\
\hline- & 1.5 & - & 65 & $3.5 \pm 0.05^{c}$ & $2.8 \pm 0.05^{\mathrm{d}}$ \\
\hline 0.5 & - & 0.5 & 50 & $5.2 \pm 0.05^{f}$ & $3.7 \pm 0.11 \mathrm{~g}$ \\
\hline 1.0 & - & 0.5 & 70 & $6.7 \pm 0.05^{h}$ & $4.1 \pm 0.15^{\mathrm{h}}$ \\
\hline 1.5 & - & 0.5 & 75 & $8.2 \pm 0.05^{\mathrm{i}}$ & $5.5 \pm 0.05 j$ \\
\hline 2.0 & - & 0.5 & 95 & $9.8 \pm 0.11 j$ & $8.3 \pm 0.11^{k}$ \\
\hline - & 0.5 & 0.5 & 60 & $4.2 \pm 0.05^{\mathrm{d}}$ & $2.4 \pm 0.05^{\mathrm{c}}$ \\
\hline - & 1.0 & 0.5 & 70 & $4.6 \pm 0.3^{e}$ & $3.8 \pm 0.05 \mathrm{~g}$ \\
\hline - & 1.5 & 0.5 & 65 & $5.7 \pm 0.05 \mathrm{~g}$ & $4.3 \pm 0.15^{\mathrm{i}}$ \\
\hline- & 2.0 & 0.5 & 55 & $5.6 \pm 0.11^{\mathrm{fg}}$ & $3.2 \pm 0.05^{\mathrm{e}}$ \\
\hline
\end{tabular}

Data represent treatment means \pm Sd followed by different letters within column indicate significant differences according to ANOVA and DMRT showed $(\mathrm{p}<0.05)$.

In vitro derived shoots $(3.0-6.0 \mathrm{~cm})$ were removed from culture tubes and separated from shoot clumps and sub-cultured on the half strength MS supplemented with NAA and IBA $(0.2-1.0 \mathrm{mg} /)$. Among all concentrations tested, the optimum root induction rate $(95 \%)$ was observed on half strength MS with IBA $(1.0 \mathrm{mg} /)$ with maximum mean number of roots $(10.4 \pm 0.05)$ and mean root length $(6.3 \pm 0.15)$ (Table 3$)$. The medium 
containing NAA $(1.0 \mathrm{mg} /)$ was reported to produce least mean number of roots $(9.8 \pm$ $0.05)$ and mean root length $(5.3 \pm 0.11)$ when compared to IBA containing rooting medium (Fig. 2a,b).

Table 3. Effect of different concentrations of auxins on rooting of in vitro derived micro-shoots of $C$. pareira on half strength MS after 20 days.

\begin{tabular}{ccccc}
\hline \multicolumn{2}{c}{ Auxins $(\mathrm{mg} A)$} & $\begin{array}{c}\text { Frequency of root } \\
(\%)\end{array}$ & $\begin{array}{c}\text { Mean values on } \\
\text { roots }\end{array}$ & $\begin{array}{c}\text { Root } \\
\text { length }(\mathrm{cm})\end{array}$ \\
\cline { 1 - 4 } NAA & IBA & 70 & $6.4 \pm 0.05^{\mathrm{a}}$ & $2.5 \pm 0.05^{\mathrm{a}}$ \\
0.2 & - & 72 & $7.6 \pm 0.11^{\mathrm{b}}$ & $3.3 \pm 0.11^{\mathrm{b}}$ \\
0.4 & - & 75 & $8.3 \pm 0.15^{\mathrm{c}}$ & $3.7 \pm 0.05^{\mathrm{c}}$ \\
0.6 & - & 80 & $9.2 \pm 0.05^{\mathrm{e}}$ & $4.3 \pm 0.05^{\mathrm{d}}$ \\
0.8 & - & 85 & $9.8 \pm 0.05^{\mathrm{f}}$ & $5.3 \pm 0.11^{\mathrm{e}}$ \\
1.0 & - & 78 & $6.3 \pm 0.05^{\mathrm{a}}$ & $3.3 \pm 0.15^{\mathrm{b}}$ \\
- & 0.2 & 85 & $7.7 \pm 0.05^{\mathrm{b}}$ & $3.8 \pm 0.05^{\mathrm{c}}$ \\
- & 0.4 & 90 & $8.6 \pm 0.11^{\mathrm{d}}$ & $4.2 \pm 0.05^{\mathrm{d}}$ \\
- & 0.6 & 94 & $9.7 \pm 0.11^{\mathrm{f}}$ & $5.2 \pm 0.05^{\mathrm{e}}$ \\
- & 0.8 & 95 & $10.4 \pm 0.05^{\mathrm{g}}$ & $6.3 \pm 0.15^{\mathrm{g}}$ \\
\hline
\end{tabular}

Data represent treatment means $\pm \mathrm{SE}$ followed by different letter(s) within column indicate significant differences according to ANOVA and DMRT $(\mathrm{p}<0.05)$.

Healthy rooted plants were carefully removed from the culture tubes and the roots were washed with sterile distilled water to remove the residues of agar (Fig. 2b). Nearly $80 \%$ survivability was recorded (Fig. 2c). There was no variation in morphology and growth characteristics of the acclimatized plants compared to the donor plants.

Plant biotechnology is well thought-out in wide sense comprises the various culture methods of plant organs and explants (Dodds and Roberts 1982). In order to establish the callus induction, it is important to optimize the condition for formation of greenish, well textured calli. Present authors reported a few concentrations of growth hormones such as the combination of BAP and NAA for the optimization of callus induction. This combination was found to be inducing maximum callus induction frequency as compared to any other treatments. Our results are accordance with the finding of Tinospora cordifolia in which maximum callus formation was observed from nodal explants when cultured on MS medium supplemented with different concentration of BAP and NAA (Singh et al. 2009). There was positive interaction result of BAP and NAA relatively in production of fast grown calli than 2,4-D alone or in combination with BAP. Callus production efficiency of BAP and NAA combination on Solanum nigrum (Sridhar and Naidu 2011) and Orthosiphon aristatus (Reshi et al. 2013) were reported. Light green 
and creamish colour calli were induced in combination of auxin and cytokinin. Such activity due to the effect of auxin on chlorophyll pigment development (Vigas et al. 2007). The nodal explants of Cyclea peltata inoculated on MS supplemented with NAA + BAP and NAA + Kn maximum callus induction was observed (Manasa et al. 2017). The increase in the auxin concentration resulted in the change of colour of callus from greenish to dark brownish, compact and hard. This is in conformity with prior report in Ipomea aqualtica (Prasad et al. 2006). If the phenolic compounds increases that leads to accumulation in the cytoplasm of cell, it undergoes oxidation and polymerization and oxidized products appear brownish black colour ( Lukas et al. 2000).

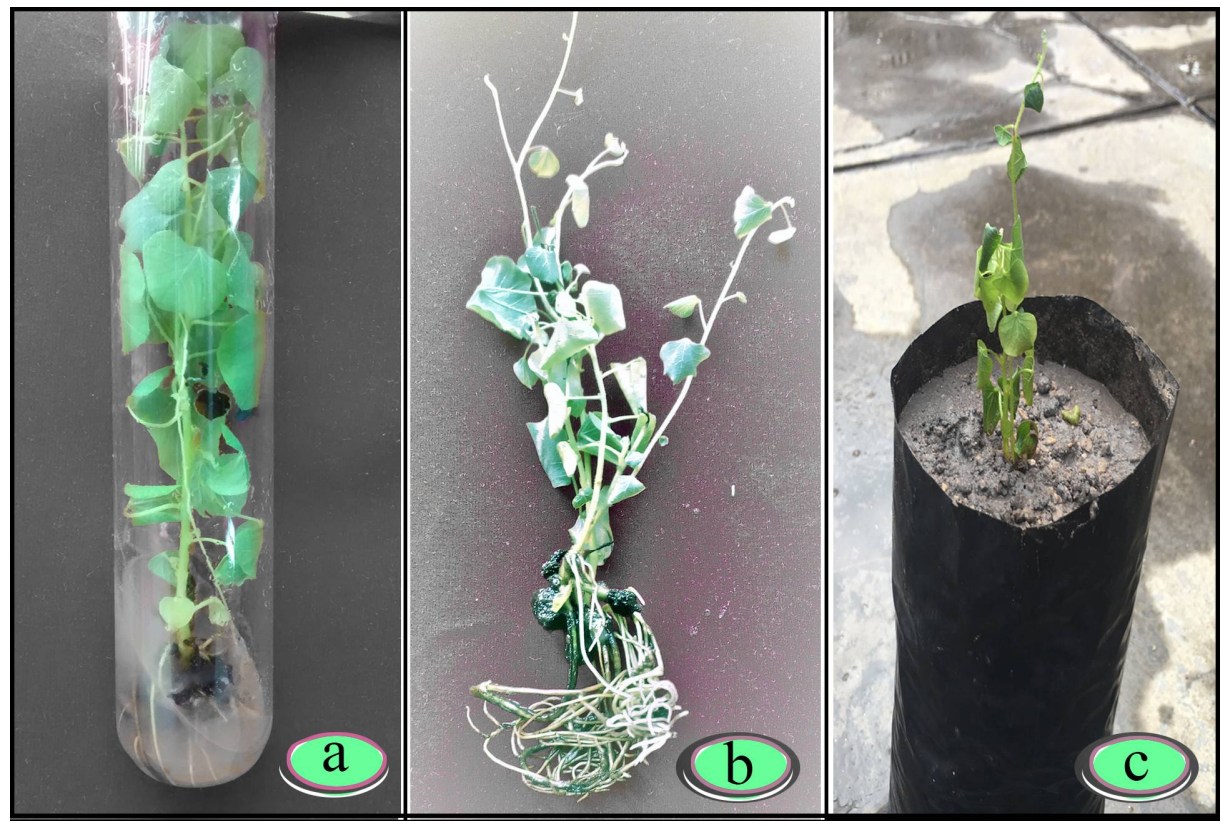

Fig. 2(a-c). In vitro rooting of regenerated shoots and hardening of Cissampelos pareira. (a) Elongation of roots from shoots. (b) Adventitious shoot with elongated rooting system. (c) Hardening of a tissue cultured plant in earthen pot containing soil and vermiculate mixture (1:1) under greenhouse condition.

In the present study in vitro regeneration of microshoots was achieved via callus. BAP $2.0 \mathrm{mg} /$ and NAA $0.5 \mathrm{mg} /$ was favourable for effective induction of multiple shoots and proliferation from calli. In general, BAP is the most efficient growth regulator for stimulation and shoot proliferation. BAP is considered to be one of the effective cytokinins for induction of organogenesis and there by effective micropropagation of plants (Sharma et al. 2003) and a combination of BAP and NAA is most often used for shoot organogenesis (Tripepi 1997). BAP alone inducing maximum number of shoots had been reported earlier in other plant like Banana (Dangi et al. 2009) and Chlorophytum borivilianum (Zahid et al. 2007). There are several reports on the positive effect of BAP and NAA on shoot regeneration. More number of shoots was obtained in Alstroemeria cv. 
by supplementing the medium with BAP $(1.5 \mathrm{mg} \Lambda)$ and NAA $(0.2 \mathrm{mg} \Lambda)$ (Seyyedyousefi et al. 2013). Similarly BAP and NAA enhanced multiple shoots in grapes by supplementing the medium with BAP (3.0 $\mathrm{mg} /)$ and NAA (0.2 $\mathrm{mg} /)$ (Khan et al. 2015). According to Butiuc-Keul et al. (2009) and Craciunas et al. (2009), cytokinins have positive effect on shoot multiplication in case of grape plant. This is due to stimulation of cytokinins on cell division which promotes axillary shoot growth (Gray 2005). If the concentration of BAP is increased that results in decreasing the shoot length due to suppression of apical dominance. At the same time decreasing the NAA concentration in the medium is important for shoot regeneration. In the present study, it is found that IBA facilitates rooting efficiently. The rooting experiment results coincided with other observation that NAA and IAA were less effective when compared to IBA in Talinum cuneifolium (Savithramma et al. 2011). Early rooting was observed in C. pareira with IBA by Gaurav and Billore (2004). Effectiveness of IBA in rooting has been reported in medicinal plants Gymnema sylvestre (Komali and Rao 2000), Hemidesmus (Sreekumar et al. 2000) and Vigna mungo (Srilatha 2014). The effectiveness of NAA in rooting has been reported for a few plant species like Decalepis hamiltonni (Reddy et al. 2001). NAA or IBA alone induced rooting reported in Cassia alata (Ramurthy 2002) and Albizzia amara (Savithramma 2003). The slow movement and slow degradation of IBA facilitates its localization near the site of application and thus it functions better in inducing roots (Nickel 1982).

\section{Acknowledgement}

The authors are grateful to Dr. M. Ramesh, Department of Biotechnology, Alagappa University, Tamilnadu and Mr. Raghupathi Lab. Assistant for helpful assistance during indirect organogenesis and maintenance of in vitro raised plantlets in the greenhouse.

\section{References}

Amod Kumar MD, Sarfaraz Ahmad and Naseem MD (2010) In vitro plant regeneration from organ cultures of Gmelina arborea Roxb. J. Indian Bot. Soc. 89(1-2): 197-203.

Butiuc-Keul A L, Coste A., Halmagyi A, Deliu C, Farago M, Iliescu M. and Iuoras R (2009) In vitro micro propagation of several grapevine cultivars from Romania . Acta Hortic. 812: 129-134

Chandra Sekhar, P, Mahadev, MD and Naidu, C.V (2014) High efficiency adventitious indirect organogenesis and plant regeneration from callus of Centella asiatica (L.) - An important anti jaundice medicinal plant. International J. Adv. Res. 2(1): 1027-1036.

Craiunas C, Butiuc-Keul A, Coste A, Oltean B , Farago M, Iliescu M and Iuoras (2009) Selection of valuble germplasm of grape vine and preservation by in vitro culture. Acta Hortic. 843-17: 145150.

Dangi M, Gill MIS and Saini HK (2009) Plantlet regeneration from unirradiated and irradiated banana shoot tips cultured in vitro. The Philippine Agriculturist 63(2): 140-146.

Dodds JH and Roberts LW (1982) Experiments in plant tissue culture. Cambridge University Press, Cambridge, London, New York. 
Gray DJ, Jayasankar S and Li Z (2005) Vitis spp. grape, In: Biotechnology of Fruit and Nut Crops. Litz R.E.(Ed.), CABI Publishing, Wallingford. pp. 672-706.

Gurav AM and Billore KV (2004) In vitro propagation of patha (Cissampelos pareira). J.D.R.A.S. 29(1-2): 39-46.

Gururaj HB, Giridhar P and Ravishankar PS (2007) Micropropagation of Tinospora cordifolia (Willd.) Miers ex Hook. F \& Thoma - A multipurpose medicinal plant. Curr. Sci. 92: 23-26.

Komalivalli N and Rao MV (2000) In vitro micropropagation of Gymnema sylvestre, a multipurpose medicinal plant. Plant Cell Tissue and Org.Cult. 61: 97-105.

Kumar S, Narula A, Sharma MP and Shrivastava PS (2003) Effect of copper and zinc on grouth, secondary metabolite content and micropropagation of Tinospora cordifolia: A medicinal plant. Phytomorphology 53: 79-91.

Lukas AM, Christoper, DG, Rebecca AS and Virgnia W (2000) AN9-a petunia glutathione stransferase required for anthocyanin sequestration, is a flavonoid binding protein. Plant Physiol. 123: 1561-1570.

Manasa DJ, Chandrashekar KR, and Bagya N (2017) Rapid in vitro callogenesis and photochemical screening of leaf, stem and leaf callus of Mussaenda frondosa Linn.: A medicinal plant. Asian J. of Pharmaceutical and Clinical Research 10(6): 81-86.

Mohd. Zahid Rizvi, Suman Preet Singh Khanuja and Arun Kumar Kukreja (2007) In vitro culture of Chlorophytum borivilianum sant. et Fernand. in liquid culture medium as a cost-effective measure. Current Sci. 92(1): 87-89.

Mridula K, Parthibhan S, Senthil Kumar T and Rao MV (2017) In vitro organogenesis from Tinospora cordifolia (Willd.) Miers - A highly valuble medicinal plant. South African J. Bot. 113: 84-90.

Nadra KHAN (2015) Optimizing the concentrations of plant growth regulators for in vitro shoot cultures, callus induction and shoot regeneration from calluses of grapes. J. Sci. Vigne Vin, 49: 37-45.

Nagendra Prasad K, Siva Prasad M, Shivamurthy GR and Aradhya SM (2006) Callus induction from Ipomoea aquatica Forsk. Leaf and its antioxidant activity. Ind J Biotech. 5: 107 -111.

Nickell GL and Kirk-Othmer (1982) Encyclopaedia of chemical technology. Vol.18 (John Wiley \& Sons) New York.

Ortiz RDC, Kellogg EA and Werff HVD (2007) Molecular phylogeny of the moonseed family (Menispermaceae): implications for morphological diversification. Am. J. Bot. 94: 1425-1438.

Prapty Das, Bhaben.T and Borthakur S. K. (2017) Effect of 2, 4-D on callus induction at nodal and internodal explants of Brucea mollis Wall. ex Kurz- an endangered plant of north-east India. Bioscience Discovery 8(3): 369-374.

Raghu V, Geetha SP, Martin G, Balachandran I and Ravindran PN (2006) In vitro clonal propagation through mature nodes of Tinospora cordifolia (Willd.) Miers ex Hook. F \& Thoma.: an important ayurvedic medicinal plant. In vitro cellular and developmental biology of plant. 17: $161-169$.

Ramamurthy $\mathbf{N}$ and Savithramma N (2002) In vitro regeneration of a medicinal plant Cassia alata L. through axillary bud. J. Plant Biology 29(2): 215-218.

Ramamurthy N and Savithramma N (2003) Shoot bud regeneration from leaf explants of Albizzia amara Biov. Indian J. Plant Physiol. 8(4): 372-376. 
Reddy BO, Giridhar P and Ravishankar GA (2001) In vitro rooting of Decalepis hamiltonii Wight \& Arn., an endangered shrub, by auxins and root-promoting agents. Curr. Sci. 81(11): 1479-1482.

Reshi NA, Sudarshana MS and Rajashekar N (2013) Callus induction and plantlet regeneration in Orthosiphon aristatus (Blume) Miq. - A potent medicinal herb. IOSR J. Pharmacy and Bio. Sci. 6: 52-55.

Savithramma N, Beena P, Sasikala A, Reddy AK and SaradvathiJ (2011) Micropropagation of Talinum cuneifolium (Vahl.) Willd. through axillary bud culture in plant tissue culture emerging trends Edited by T. Pullaiah. Regency Publications, Delhi. 103-113.

Seyyed Rahim Seyyedyousefi (2015) The effect of different concentrations of NAA and BAP on micropropagation of Alstroemeria. European Journal of Experimental Biology 3(5): 133-136.

Shad V and Deepa MA (2015) Elicitation, bioconversion and quantification of berberine from Cissampelos pariera callus cultures. Int. J. Pharmaceut. Sci. Res. 6: 2636-2640.

Sharma H and Vashistha BD (2014) In vitro callus initiation and organogenesis from shoot tip explants of Tinospora cordifolia (Willd) Miers ex Hook. F \& Thoma. CIB Tech J. Biotechnology. 3: 2319-2359.

Sharma PK, Tyagi P, Sharma KC and Kothari SL (2003) Clonal microproagation of Crateva adansonii (DC.) Prod.: A multipurpose tree. In Vitro Cell. Dev. Biol. Plant 39: 156-160.

Singh A, Saroja SK, Pradhan A, Rajbahak S and Maharajan ( 2009) In vitro study of Tinospora cordifolia (Willd) Miers (Menispermaceae) Bot. Orien. 6:103-105.

Sreekumar S, Seeni S and Pushpangadan P (2000) Micropropagation of Hemidesmus indicus for cultivation and production of 2-hydroxy 4-methoxy benzaldehyde. Plant Cell. Tissue Organ Culture 62: 211-218.

Sridhar TM and Naidu C (2011) An efficient callus induction and plant regeneration of Solanum nigrum (L.) - An important antiulcer medicinal plant. Journal of Phytology 3: 23-28.

Srilatha T (2014) Direct plant regeneration from cotyledonary explants of black gram (Vigna mungo L.) Hepper. Int. J. Pharm. Bio. Sci. 5 (2): 491-497.

Sun Y, Xun K, Wang Y and Chen X (2009) A systemic review of the anticancer properties of berberine, a natural product from Chinese herbs. Anticancer Drugs 20: 757-769.

Tripepi RR (1997) Adventitious shoot regeneration. In: Geneve RL, Preece JE and Merkle SA (Eds.), Biotechnology of ornamental plants. Wallingford, UK: CAB International. pp. 55-71.

Vaidya BG (1988) Nighantu Adarsh. Vol.1. Chaukhambha Bharti Academy Publications, Varanasi, India. 44-45.

Viegas J, Da Rocha MTR, Ferreira-Moura I, Da Rosa DL De Souza JA, Correa MGS and Da Silva JAT (2007) Anthurium andreanum (Linden ex Andre) culture. In vitro and ex vitro. Floriculture Ornamental Biotechnology 1(1): 61-65.

Wang Y, Huang Y, Lam KS, Li Y, Wong WT, Ye H, Lau CW, Vanhoutte PM and Xu A (2009) Berberine prevents hyperglycemia-induced endothelial injury and enhances vasodilatation via adenosine monophosphate-activated protein kinase and endothelial nitric oxide synthase. Cardiovascular Research 82: 484-492. 